\title{
Experts' Perceptions of the Effects of Forest Biomass Harvesting on Sustainability in the Alpine Region
}

\author{
Gianluca Grilli 1,2, Giorgio Curetti 2, Isabella De Meo ${ }^{3}$, \\ Giulia Garegnani ${ }^{2}$, Francesca Miotello ${ }^{4}$, Aleš Poljanec 5 , \\ Daniele Vettorato ${ }^{2}$, Alessandro Paletto ${ }^{6}{ }^{\sharp}$
}

1 University of Trento, Department of Civil, Environmental and Mechanical Engineering, via Mesiano 77, I-38123 Trento, Italy

2 EURAC Research, Institute for renewable Energy, Viale Druso 1, I-39100 Bolzano, Italy

${ }^{3}$ Consiglio per la Ricerca in Agricoltura e I'analisi dell'economia agraria (CRA), Agrobiology and Pedolog Centre, P.zza Massimo D’Azeglio 30, I-50121, Firenze, Italy

${ }^{4}$ Regione del Veneto, Department of Economy and Development in Mountain Areas, Palazzo Balbi Dorsoduro 3901, I-30123 Venezia, Italy

5 University of Ljubljana, Biotechnical faculty, Department for forestry and renewable forest resources, Večna pot 2, SI-1000 Ljubljana, Slovenia

${ }^{6}$ Consiglio per la Ricerca in Agricoltura e I'analisi dell'economia agraria (CRA), Forest Monitoring and Planning Research Unit, Piazza Nicolini, 6 Loc. Villazzano, I-38100, Trento, Italy

Corresponding author: e-mail: alessandro.paletto@entecra.it

Citation:

GRILLI G, CURETTI G, DE MEO I, GAREGNANI G, MIOTELLO F, POLANEC A, VETTORATO D, PALETTO A 2015 Experts' Perceptions of the Effects of Forest Biomass Harvesting on Sustainability in the Alpine Region. South-east Eur for 6 (1): 77-95. DOI: http://dx.doi.org/10.15177/seefor.15-01

\section{Abstract}

Background and Purpose: In the EU political agenda, the use of forest biomass for energy has grown rapidly and significantly, in order to mitigate carbon dioxide emissions and reduce the energy dependence on fossil fuels of European member countries. The target of the EU climate and energy package is to raise the share of renewable energy consumption produced from renewable resources to $20 \%$ in 2020 (Directive $2009 / 28 / E C$ ). With regards to biomass energy, the supply of forest wood biomass is expected to rise by 45\% (reference period: 2006-2020), in response to increasing demand for renewable sources. The increase of forest biomass supply could have both positive and negative effects on several forest ecosystem services (ESs) and local development. These effects should be assessed in a proper manner and taken into account when formulating management strategies. The aim of the paper is to assess the environmental, economic and social sustainability of forest biomass harvesting for energy, using the Figure of Merit (FoM) approach. Materials and Methods: Sustainability was assessed through a set of four indicators: two focused on experts' opinions regarding the effects of forest biomass harvesting and the other two focused on the cost-benefit analysis (potential energy obtained and costs for wood chips). The research was developed through four case studies located in the Alpine Region. A semi-structured questionnaire was administered 
face-to-face to 32 selected experts. The perceived effects of forest biomass harvesting for energy on ESs and local development were evaluated by experts using a 5-point Likert scale (from "quite negative effect" to "quite positive effect").

Results: All experts agree that forest biomass harvesting has a positive effect on forest products provision and local economic development (employment of local workforce, local entrepreneurship and market diversification), while the effects on other ESs are controversial (e.g. carbon sequestration, habitat quality, natural hazards protection and recreational values).

Conclusions: Therefore, it can be asserted that the effects of forest biomass harvesting on sustainability vary according to the local context. The results of FoM can support decision makers in order to analyze the environmental, social and economic sustainability of forest biomass harvesting for energy.

Keywords: ecosystem services, ecological effects, socio-economic effects, local development, Multi-Criteria Analysis, Alpine Space

\section{INTRODUCTION}

At global level, renewable energies cover more than $13 \%$ of the world's energy demand [1] and they could meet more than $50 \%$ of the total energy demand by the middle of $21^{\text {st }}$ century, if supported by appropriate energy policies and innovative renewable energy technologies development [2]. In the pool of renewable energies, wood and wood wastes cover about $47 \%$ of the gross consumption of all renewable energy in the European Union in 2011 and $67 \%$ of bioenergy use [3].

According to the European Union (EU) Forest Action Plan of the period 2007-2011 [4], the $27 \mathrm{EU}$ member countries have a high energy potential from forests, despite the relevant constraints to wood mobilization [5]. EU Forest Action Plan considers the promotion of use of forest biomass for energy generation one of the 18 key actions to improve the competitiveness of the European forest sector [6]. Subsequently, the new EU Forest Strategy (2013) encourages to use forest resources in a manner that minimizes the negative impact on the environment and prioritizes the outputs that have higher addedvalue and are able to create job opportunities.

In 2005 around 98 million $\mathrm{m}^{3}$ of wood overbark was removed from EU forests and used as fuelwood [7]. This wood quantity for energy purpose is foreseen to increase in future decades, because the targets of the EU climate and energy package are to raise the share of renewable energy consumption produced from renewable resources to $20 \%$ in 2020 and to reduce the greenhouse gas (GHG) emissions by $20 \%$ compared to 1990 levels (Renewable Energy Directive 2009/28/EC). EUwood estimates that the EU's forest biomass supply would increase by $11 \%$ from 2010 to 2030, while the demand for forest biomass would rise by $73 \%$ [8]. Other studies evaluate an increase in the use of renewable biomass by $45 \%$ by volume between 2006 and 2020, this value representing $8 \%$ of expected total increase in renewable energy use in EU member countries $[9,10]$. Instead, Nabuurs et al. [11] for the whole Europe estimate that forests could supply 729 million $\mathrm{m}^{3}$ of wood overbark for energy use by 2060 .

According to the UNCED's report "Our common future" (1987) - better known as Brundtland report [12] - the sustainable development can be defined as the kind of development that meets the needs of the present without compromising the ability of future generations to meet their own needs. However, this definition is more focused on the economic aspects of the sustainability concept, considering only marginally environmental and social aspects. Currently, the need to consider simultaneously these three perspectives is widely recognized; in this direction in recent decades two models have been developed, with the aim to analyze the interrelationships between the environmental, social and economic aspects 
of sustainability [13]. The first model considers the three aspects as concentric ("concentric model"), while in the second model the three aspects are represented equally ("overlapping circles model"). According to the "concentric model" of sustainability, the economy sphere is a subset of the society sphere, and the latter is a subset of the environmental sphere. In the "overlapping circles model" of sustainability the three spheres are not concentric and the model considers in more detail the nature of each sphere and the reciprocal interactions. In the bioenergy sector the "overlapping circles model" is the most suitable model in order to assess the effects of biomass harvesting from forests considering simultaneously environmental, economic and social sustainability [14].

Environmental sustainability can be defined as "a condition of balance, resilience, and interconnectedness that allows human society to satisfy its needs while neither exceeding the capacity of its supporting ecosystems to continue to regenerate the services necessary to meet those needs nor by our actions diminishing biological diversity" [15]. Environmental sustainability refers to the concept of ecosystem services (ESs) first introduced in the early 80 's by Ehrlich and Ehrlich [16]. In the 90's several authors analyzed this concept through different perspectives [17, 18]. Currently, ESs can be defined as the benefits obtained from nature that satisfy human needs $[19,20]$ such as provisioning services (e.g. food, fodder and timber), regulating services (e.g. air and water purification), cultural services (e.g., recreational opportunities), and supporting services (e.g. nutrient cycling). Many attempts have been made both to systematically categorize and to comprehensively list ESs [20-22].

Sustainability of economy - in the strict sense - is considered as the ability to maintain productivity [23]. In a broader sense, sustainable growth is the creation of a social and economic system which provides support to increase the real income, to improve the level of education, and to improve the quality of life $[24,25]$.
While, social sustainability is defined as a life-enhancing condition within communities and a process within communities that can achieve that condition [26]. The key aspects to consider in social sustainability are [27]: equity of the current generation access to fundamental services (e.g. health, education) and equity between generations, widespread people's participation to the decisions, a sense of community responsibility, respect for property rights. Social sustainability can be implemented incorporating perceptions, preferences and opinions of local community, stakeholders or public in general in the decision making process, following the basic principles of participatory approach [28].

Wood biomass from forests (e.g. harvesting residues as branches and tops, stumps and coarse roots, dead trees, etc.) could satisfy an interesting percentage of the energy demand through improving the efficiency of harvesting and mobilization technologies, increasing the use of biomass in the high forested areas and in the regions with a high rate of natural regeneration (i.e. mountain and marginal areas). In this potential future scenario an important aspect to take into account is the analysis of the sustainability of forest biomass harvesting for energy use, considering the effects on the environment and society. Starting from these considerations, the aim of the paper is to analyze the sustainability of forest biomass harvesting for energy purpose considering the environmental, economic and social sustainability according to the "overlapping circles model". The sustainability of forest biomass harvesting was analyzed through the use of the Figure of Merit (FoM), taking into consideration simultaneously the environmental, social and economic aspects of sustainability as well as expected from the "overlapping circles model". The research was developed in four case studies located in Alpine Region and involved in the Recharge.green project [29]. The case studies considered - Triglav National Park in Slovenia, Gesso-Vermenagna, Mis and Maè valleys in Italy - were chosen taking into account different environmental and socioeconomic contexts, in order to test the method in various situations and to compare the results. 


\section{MATERIALS AND METHODS}

\section{Study Areas}

The sustainability of forest biomass harvesting was analyzed in four case studies, located in different parts of the Alps (Figure 1): Triglav National Park (Slovenia), Mis valley and Maè valley (Belluno Province, Italy) and valley (Cuneo Province, Italy). These four case studies were chosen in order to represent various Alpine conditions. The key variables used to select the study areas were: (1) forest cover, (2) percentage of land under protected-area status (from 100\% of Triglav National Park to $45 \%$ of Maè valley); (3) tourist importance in terms of average annual number of visitors; (4) importance of primary sector for local economy (e.g. timber and hay production). Among the available data across the four study areas, these variables were chosen as proxies for many ecosystem services (in particular for provisioning, cultural and regulating services) [30].

The first study area is the Triglav National Park (TNP), located in the north-east part of Slovenia. TNP is the only national park in Slovenia and the current boundaries are established by a National Law of the 2010. TNP covers an area of almost $840 \mathrm{~km}^{2}$ which is nearly four per cent of the Slovenian surface. The main land uses are: forests (62\%) and managed grasslands (10\%). The typical forest types in the park are: European beech forests (27981 ha), dwarf mountain pine forests (11350 ha), Silver fir-European beech forests (4925 ha), and Silver fir-Norway spruce forests (4191 ha). The park provides a variety of ESs. On the one hand nature conservation, environment and cultural heritage protection as well as recreation and tourism (about 580000 tourists per year) are the most important ESs in TNP; on the other hand agriculture and forestry are important for the people living in the park.

Mis Valley covers an area of 11800 ha and it is crossed by Mis Stream (22 km long). It includes two municipalities and large part of the area is covered by the Dolomiti National Park $(71 \%$ of Mis valley). Forest area covers about 8347 ha and the main forest categories are hornbeam and manna ash forests (2420 ha), European beech forests (2133 ha), dwarf mountain pine forests (1442 ha) and Norway spruce forests (533 ha). Considering the area covered by forest management unit plans, the mean growing stock is nearly $214 \mathrm{~m}^{3} \cdot \mathrm{ha}^{-1}$ with a current annual increment of $3.78 \mathrm{~m}^{3} \cdot \mathrm{ha}^{-1} \cdot \mathrm{year}^{1}$. The tourism sector is less developed and the visitors are mainly concentrated in the area of the Dolomiti National Park.

Maè Valley covers an area of 23300 ha around

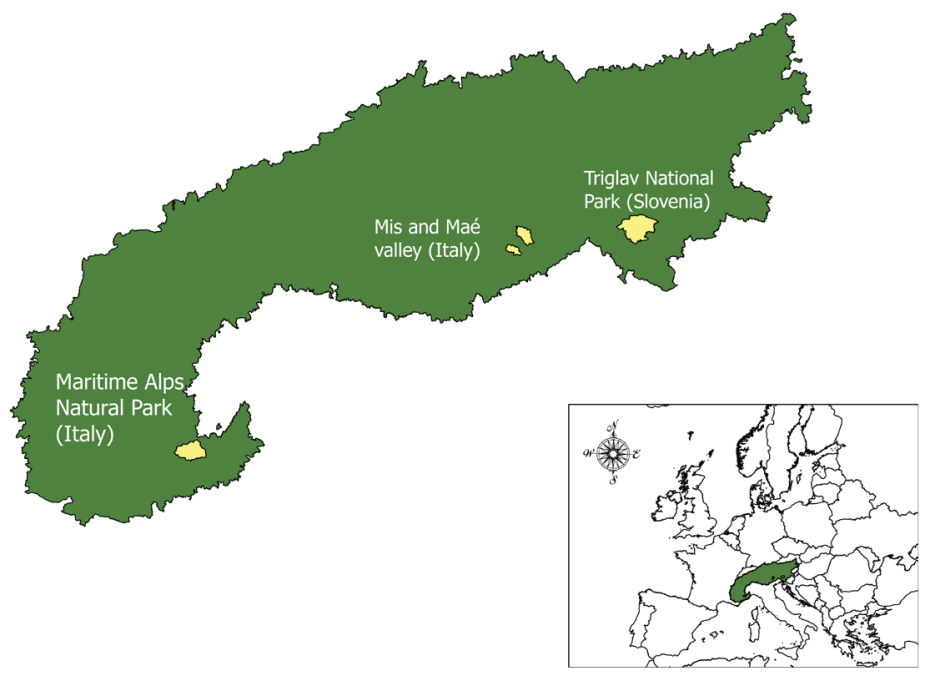

FIGURE 1. Geographical location of the study areas in the Alpine Region (source: Alpine Convention, SOIA database for alpine perimeter, EUROGEOGRAPHICS for administrative boundaries). 
the Maè Stream (33 km long), and it includes four municipalities. The area is part of Natura2000 Network, Dolomiti UNESCO site and Dolomiti National Park ( $45 \%$ of total land area). In the past Maè valley was characterized by traditional use of wood for rural building structures, now strongly declined. Nowadays the use of wood for heating remains high for households' traditional activity. Regarding the forest area (18928 ha), the main forest categories are European beech forests (3963 ha), dwarf mountain pine forests (2532 ha) and mixed forests of Norway spruce and European beech (2167 ha). Considering the area under forest management unit plans, the mean growing stock is nearly $208 \mathrm{~m}^{3} \cdot \mathrm{ha}^{-1}$ with a average annual increment of $3.50 \mathrm{~m}^{3} \cdot$ ha $^{-1}$ year ${ }^{-1}$. In this area the tourism sector is less developed with an average number of visitors per year equal to 40000 .

Gesso-Vermenagna valley is located in the north-western part of Italy (Piedmont Region), close to the French border. The study area includes seven municipalities. The land area is approximately 51500 ha of which about 32000 ha are located in protected areas (Maritime Alps Natural Park or Nature2000 sites). The main land uses are forests (42\%) and pastures (33\%). The main forest types are European beech forests with 11500 ha, chestnut forests with $2700 \mathrm{ha}$, and mixed forests (maple, linden and ash) with $1850 \mathrm{ha}$. The average standing stock is $183 \mathrm{~m}^{3} \cdot \mathrm{ha}^{-1}$, with an average annual increment of $7.73 \mathrm{~m}^{3} \cdot$ ha $^{-1}$.year ${ }^{-1}$. Gesso-Vermenagna valley is a mountainous area mainly based on the primary sector (about $22 \%$ of total firms), while the secondary sector (industry) is poorly developed.
The services sector is based on tourism with an average of 121000 visitors per year.

\section{Research Framework}

The sustainability of forest biomass harvesting for energy production was assessed through a set of four indicators: (1) perceived effects of forest biomass harvesting on ESs; (2) perceived effects of forest biomass harvesting on local development; (3) potential energy obtained from forest biomass; (4) costs for energy production. The first two indicators focused on the local experts' opinions concerning the effects of forest biomass harvesting on ESs and local development, while the other two indicators focused on the cost-benefit analysis (potential energy obtained and costs for wood chips). The data of the first two indicators were collected through a semistructured questionnaire, while the other two indicators were quantified using data from ad hoc survey and forest management plans.

The experts were identified by the researchers of the Recharge.green project and the local partners in a brainstorming session. The major selection criterion was their professional experience in one of the following sectors: forest management and planning, environment conservation, rural development and renewable energy development. Besides, the experts were chosen on the basis of their expertise and knowledge of the local context. The experts identified in each case study were mainly policy makers and technicians. At the end of this preliminary stage, a total of 32 experts - distributed as illustrated in Table 1 - were identified and directly contacted.

TABLE 1. Number of experts interviewed subdivided per study area

\begin{tabular}{llc}
\hline \multicolumn{1}{c}{ Country } & \multicolumn{1}{c}{ Study area } & $N^{\circ}$ experts \\
\hline \multirow{3}{*}{ Italy } & Mis valley (Veneto Region) & 5 \\
& Maè valley (Veneto Region) & 6 \\
& Gesso-Vermenagna valley (Piedmont Region) & 8 \\
Slovenia & Triglav National Park (Gonška Region) & 13 \\
\hline Total & & 32 \\
\hline
\end{tabular}


The semi-structured questionnaire administered to the experts was subdivided in 6 thematic sections and composed by 20 questions (19 close-end questions and one open-end question). In the present paper the data of the two thematic sections concerning forest biomass harvesting (effects on ESs and on local development) were used to elaborate the indicators of sustainability.

The semi-structured questionnaire was administered through face-to-face interviews to the local experts identified in the period September 2013 - July 2014. For each question, besides ticking the given answer, there was discussion, in order to collect comments and explanations for responses and to discuss the various related aspects with the experts. The discussion was assumed to help to interpret the quantitative results and, furthermore, it was helpful in case experts had difficulty in understanding the meaning of some words or concepts. In the present paper qualitative information collected during the interviews were used in the discussion of the results in order to explain and understand the differences between case studies.

\section{Figure of Merit and Set of Indicators}

A useful and practical tool for a multi-criteria analysis of the sustainability of biomass harvesting for energy is represented by the figure of merit or FoM [31]. FoM tool allows the integration and the simultaneous comparison of several indicators of environmental, economic and social sustainability of bioenergy development. FoM tool is a simple and straightforward method that through a set of indicators allows to compare the performance of a device, system or method, relative to its alternatives. In literature, FoM is applied to assess the performance of different renewable energies (e.g. solar, wind, hydropower), on the basis of a set of performance indicators [32]. In this paper FoM was modified and adapted, in order to assess the performance of forest biomass harvesting for energy in different case studies considering the local characteristics. In other words, FoM tool was used in order to compare the performance of the same activity in different geographical and socio-economic contexts.
The first two indicators (perceived effects of forest biomass harvesting on ESs and on local development) were measured using data from questionnaires responses rated on a 5-pointLikert scale ranging from -2 to +2 . The value of the other two indicators (potential energy obtained from forest biomass; costs for energy production) can range from 0 to an undefined upper limit. In these cases the range was calculated from the interval of variation given by the difference between the best and the worst performance of each case study.

For each indicator, the range of scores was divided into 10 equal classes. In this way, for the indicators 1 and 2 each class has a width equal to 0.4 . For the indicators 3 and 4 , the width of the classes was calculated dividing in 10 equal parts the range obtained from minimum to maximum value of the indicator. Finally, each indicator obtains a class-relative rank according to its performance from 1 (the best score) to 10 (the worst score) [1]. In the present study the same level of importance to each indicator has been given, without attributing different weights. The formula used to calculate the FoM was:

$$
\begin{gathered}
\text { FoM }=\text { Relative rank } I_{1} \text { * Relative rank } I_{2} \text { * } \\
\text { Relative rank } I_{3} \text { * Relative rank } I_{4}
\end{gathered}
$$

where:

$\mathrm{I}_{1}=$ perceived effects of forest biomass

harvesting on ESs (range from -2 to 2);

$\mathrm{I}_{2}=$ perceived effects of forest biomass

harvesting on local development

(range from -2 to 2 );

$\mathrm{I}_{3}=$ potential energy obtained from forest

biomass considering tree composition of

forest types (MJ.ha ${ }^{-1}$.year ${ }^{-1}$ )

$\mathrm{I}_{4}=$ unit cost for energy production

( $€ \cdot \mathrm{t}^{-1}$ fresh chips).

The first indicator $\left(I_{1}\right)$ is associated to the perceived effects of forest biomass harvesting for energy on ESs. In this study six ESs provided by Alpine forests were considered and assessed, assuming the commensurability of these ESs (Table 2). This set of ESs reflects both the particular mountain ecosystems characteristics 
and the decision making context (expanding renewable energies in general and bioenergy in particular for the local development) [33].

For each case study the experts evaluated the positive and negative effects of forest biomass harvesting using a 5-point Likert scale $(-2=$ quite negative effect, $-1=$ negative effect $0=$ no effect, 1 = positive effect, 2 = quite positive effect). The experts assessed the effects with special regards to the environmental characteristics of the local context. This indicator is considered as a benefit in case of positive effects and as an environmental cost in case of negative effects.

The second indicator $\left(\mathrm{I}_{2}\right)$ used in the FoM has the purpose to evaluate - through the experts' opinions - the positive and negative perceived effects of forest biomass harvesting on local development, considering the socio-economic characteristics of the study area. The effects were assessed using three dimensions related to different features of local development: economic, social and cultural. For each effect dimension were selected appropriate subindicators. The experts assessed the effects on each sub-indicator taking into account all aspects described in Table 3 in an aggregate way.

Economic indicators track the costs and business aspects of a process. When considering sectors such as renewable energies production, these indicators must go beyond conventional financial reporting to describe the creation of wealth and its distribution and reinvestment for future growth [34]. The hypothesis is that

TABLE 2. Alpine ecosystem goods and services considered in this paper (source: [20-22])

Ecosystem good and service

\section{Provisioning services}

Provision of forest and agricultural production

Provision of fresh or potable water

\section{Regulating and maintenance services}

Protection against natural hazards

Carbon sequestration in vegetation and soil

Ecological habitat quality

\section{Cultural services}

Recreational values

\section{Definition adopted}

Products obtained directly from ecosystems such as agricultural products, forest products and aquaculture products. If relevant, could also include extractable products (e.g. mushrooms, natural medicines, peat, ...)

Provision of fresh or potable water including water filter function of soils

Mediation/Buffering of flows (mass, liquid, gaseous) for avoiding extreme events (such as floods, soil erosions, landslides, avalanches, storms, rock falls, ...)

Amount of carbon sequestrated by the ecosystem for regulating the global atmospheric composition The overall habitat quality for wild plant and animal species, necessary for the function of ecosystem services mentioned above. Habitat quality is (mutually) dependent on nutrient cycling, seed dispersal and pollination. Also, the long term ecosystem stability (=resilience) and resistance against pests affecting human health and forestor agricultural production are an expression of high ecological habitat quality

Value for recreation (such as walking, hiking, skiing, climbing, boating, leisure fishing and leisure hunting), possibility for relaxation and silence in general 
TABLE 3. Socio-economic effects on local development considered in this paper (source: [37-47])

Indicator Ambit Description and related issues

\section{Economic indicators}

Local market Local economy

diversification

Allocation of resources over a large number of markets in an attempt to reduce risks of concentrating resources and to exploit the economies of flexibility [44].

Willingness to invest in renewable energies to diversify the market.

System flexibility to react to market changes and to renewable energies price fluctuations.

Local Local economy

Propensity of the local population to initiate business enterprises'.

Effects on business opportunities and productive diversification of the area.

Resource efficiency Local economy Use of natural resources, with the main purpose of minimising their input when producing a product or delivering a service. Amount of energy production with a less amount of nonrenewable resource input.

\section{Social indicators}

Employment of Quality of life local workforce

Improving the economic development of local community. The installation, operation and maintenance of renewable energy technologies are generally of modest scales, so they create more employment, for the local workforce.

Building the technical capacity of the local workforce.

Increasing income Quality of life per capita

Income per capita is a positive variable of social welfare, and is often an effect of technical progress [41].

Payments to local farmers for hiring their land and "compensations" to the local community made by the owner of the renewable energy plant.

Tourism Quality of life

Renewable energies development creates changes in the area and effects on tourism development. Attractiveness of the area for visitors is an indicator of social development.

Social and

community

aggregation

Political stability

Human health

$\begin{array}{ll}\text { Human health } & \begin{array}{l}\text { Health and } \\ \text { safety }\end{array}\end{array}$

\section{Cultural indicators}

Property rights and

Local traditions rights of use
Social stability, involvement and legitimacy

Social stability, involvement and legitimacy Health and and values
Effects on the capacity to improve local people participation (i.e social and political empowerment, participative decisionmaking, participatory integrated assessment)

Effect on social capital and on community capacity-building

Citizens' acceptance of the system or, in other words, the potential of conflicts induced by energy systems, and the citizens participation in the decision making process.

Health hazards for the local population linked to the renewable energies production (potential health impact due to severe accidents; health consequences of normal operations).

Land and resource tenure, dependencies on foreign sources (e.g. financial investments, knowledge), customary rights 
encouraging the use of forest biomass for energy purposes has positive economic effects at local level. In particular, the positive effects concern the market diversification (e.g. wood chips as efficient alternative to traditional fuelwood), the creation of new job opportunities in the forest-wood-energy chain, and the impetus for innovation and local entrepreneurship.

Social indicators are employed to assess both the technological impacts, and the effects of political strategies, interventions or plans. There are various models for the measurement of social impact and the discipline of social indicator research provides a vast list of works on which to base the choice and selection of appropriate indicators [35]. In the present work, social sub-indicators were used in order to take into account three main ambits: quality of life of people, socio-political stability and health and safety. The hypothesis is that the use of forest biomass for energy can potentially have positive effects on the quality of life of local communities (increase employment opportunities and income per capita), but - on the other hand - it can also have potentially negative effects on the health and safety of forest workers.

The term cultural indicator is a term developed by Gerbner [36] and refers to the elements that reflect our culture. The local culture can influence the rational choices of the people (i.e. political decision makers, managers, members of community) but, conversely, in a long term period the economic investments and the land use changes can influence the local culture. Consequently, the cultural indicators have the purpose to quantify the potential impacts of an investment on cultural aspects in a specific territory. Considering the roots of cultural aspects in the context, it is assumed that the use of forest biomass for energy purpose has no effect in the short and medium term on cultural indicator. The potential positive effects may be found only in the long term.

For the purposes of the present study, the authors selected 10 sub-indicators ( 3 economic indicators, 6 social indicators and 1 cultural indicator) in order to evaluate the effects of forest biomass utilization for energy production on local development in selected study areas.

The 10 sub-indicators are described in Table 3, evidencing their economic, social and cultural impact dimension, the specific ambit of the impact, and the indicator features. The ambit of impact of forest biomass harvesting concerns: i) the impact on the local economy, ii) the impact on the quality of life, iii) the impact on the social stability, involvement and legitimacy, iv) the impact on health and safety and $v$ ) the impact on local traditions and values. The description of each indicator moves from the general definition to the specific issues related to forest biomass for energy purpose.

For each case study the local experts evaluated the effects of forest biomass harvesting on local development using a 5-point Likert scale (-2 = quite negative effect, $-1=$ negative effect, $0=$ no effect, $1=$ positive effect, 2 = quite positive effect").

The third indicator $\left(\mathrm{I}_{3}\right)$ considers the annual potential primary energy that can be obtained from forest biomass in each case study considering as key variables the annual increment $\left(\mathrm{m}^{3} \cdot \mathrm{ha}^{-1}\right.$ year $\left.{ }^{-1}\right)$ and the tree composition per forest types. The fuel has an amount of energy - called primary energy - that is converted through combustion in final energy to be used for heating or hot water for sanitary purposes [48]. For this analysis, the calorific values of the main Alpine tree species with a moisture content of $15 \%$ (dry wood) were considered (Table 4). Calorific value indicates the amount of heat that develops from the mass (weight) in its complete combustion with oxygen in a calorimeter standardize. In the last step, the calorific value of each tree species $\left(\mathrm{kcal} \cdot \mathrm{kg}^{-1}\right)$ was transformed in energy content $\left(\mathrm{MJ} \cdot \mathrm{kg}^{-1}\right)$ using the specific wood density. The energy content allowed to calculate the potential energy that can be obtained in a hectare of forest in each case study. Energy potential is considered as a benefit which can be transformed in monetary terms using the local market price.

The last indicator $\left(\mathrm{I}_{4}\right)$ considers the costs per ton of wood chips, taking into account the 
TABLE 4. Energy content of main tree species present in the case studies

\begin{tabular}{lccc}
\hline \multicolumn{1}{c}{ Tree species } & $\begin{array}{c}\text { Wood density } \\
\left(\mathrm{kg} \cdot \mathrm{m}^{-3}\right)\end{array}$ & $\begin{array}{c}\text { Calorific value } \\
\left(\mathrm{kcal} \cdot \mathrm{kg}^{-1}\right)\end{array}$ & $\begin{array}{c}\text { Energy content } \\
\left(\mathrm{MJ}^{\prime} \cdot \mathrm{kg}^{-1}\right)\end{array}$ \\
\hline Norway spruce (Picea abies) & 450 & 4857 & 20.33 \\
Silver fir (Abies alba) & 440 & 4650 & 19.47 \\
Dwarf mountain pine (Pinus mugo) & 500 & 4130 & 17.29 \\
Chestnut (Castanea sativa) & 580 & 4599 & 19.25 \\
European beech (Fagus sylvatica) & 750 & 4617 & 19.33 \\
Ash (Fraxinus excelsa) & 720 & 5350 & 22.40 \\
Maple (Acer spp.) & 740 & 4607 & 19.29 \\
Hop-hornbeam (Ostrya carpinifolia) & 820 & 4640 & 19.42 \\
Alder (Alnus spp.) & 540 & 4440 & 18.59 \\
\hline
\end{tabular}

14.186 coefficient used to obtain KJ from kcal. Source: modified by Ilarioni [49].

local productivity and costs. Four type of costs are considered in this indicator: harvesting costs, extraction costs using tractor with winch, chipping costs and transport costs (average distance around $25 \mathrm{~km}$ ). Labour costs are included in each indicator. The main factor that influences machine cost estimation is the annual utilization rate of machinery; this factor depends mainly on technical reliability of machines, roads conditions, logistics [50]. The labour cost estimation is influenced by the local costs of life and the specific conditions of local workforce in forest sector.

\section{RESULTS}

The sustainability of forest biomass harvesting for energy was assessed through a set of four indicators and in a synthetic way, using the figure of merit (FoM). Firstly, we show the results of each indicator and subsequently we evidence the results of FoM.

$I_{1}$ was calculated as the mean value of the experts' perceived effects of forest biomass harvesting on ESs (Table 5). The effects can be both negative and positive and are strongly influenced by the local context (e.g.

TABLE 5. Mean value of perceived effects of forest biomass harvesting on ESs $\left(\mathrm{I}_{1}\right)$ by case study

\begin{tabular}{lcccc}
\hline \multicolumn{1}{c}{ ESs/Case study } & $\begin{array}{c}\text { Triglav National } \\
\text { Park }\left(n^{1}=13\right)\end{array}$ & $\begin{array}{c}\text { Mis valley } \\
(n=5)\end{array}$ & $\begin{array}{c}\text { Maè valley } \\
(n=6)\end{array}$ & $\begin{array}{c}\text { Gesso- } \\
\text { Vermenagna } \\
\text { valley }(n=8)\end{array}$ \\
\hline Forest products provision & 1.31 & 1.20 & 1.50 & 0.29 \\
Water provision & 0.00 & 0.00 & 0.17 & 0.00 \\
Natural Hazards Protection & -0.23 & 0.50 & 1.17 & 0.14 \\
Carbon sequestration & -0.15 & -0.20 & 0.50 & 0.00 \\
Habitat quality & -0.62 & 1.00 & 1.33 & -0.14 \\
Recreational value & 0.08 & 0.80 & 1.67 & -0.29 \\
\hline Indicator 1 (mean) & 0.07 & 0.55 & 1.06 & 0.00 \\
\hline
\end{tabular}

${ }^{1} \mathrm{n}=$ number of experts in the study area 
presence of protected area, geomorphological and orographic conditions) and the forest management strategies adopted (e.g. silvicultural treatments). Results in Table 5 show that all experts considered positive the effect of forest biomass harvesting on forest products provision (e.g. timber and bioenergy production), with average values ranging from 0.29 in GessoVermenagna valley and 1.50 in Maè valley. Most experts agreed that the removal of woody biomass has negligible effect on the provision of fresh or potable water (average values ranging from 0 to 0.17 ).

The effects of biomass harvesting on the protection against natural hazards were considered as positive by the experts of the three case studies located in Italy, while negative $(-0.23)$ by the experts of Triglav National Park. According to their answers during the interviews, the Slovenian experts took in consideration the fact that harvesting logging residues increases soil compaction and erosion in fine textured and moist soils, and this aspect is particularly relevant in protected areas (e.g. biotopes).

Concerning the effects on carbon sequestration in vegetation and soil, the experts of
Triglav National Park and Mis valley considered as negative the overall effect $(-0.15,-0.20)$, while the experts of the other two case studies perceived a neutral or moderately positive effect.

The effects of forest biomass harvesting on habitat quality were perceived as positive by Mis valley (1.00) and Maè valley (1.33) experts, while by experts of the Triglav National Park and Gesso-Vermenagna valley were perceived as negative $(-0.62$ and -0.14$)$.

Also the experts' opinions regarding the effects on recreational value show divergences among case studies. In this case, effects of biomass harvesting were judged negatively in Gesso-Vermenagna valley (-0.29), while were considered positive in Triglav National Park, Mis and Maè valleys $(0.08,0.80,1.67)$.

The results of the second indicator $\left(\mathrm{I}_{2}\right)$, concerning the perceived effects of biomass harvesting on local development, are shown in Table 6. Results evidence that the effects of forest biomass harvesting on local development were considered as positive in all case studies for almost all indicators. Four sub-indicators obtained scores over 1 in all case studies, which are the following: local market diversification,

TABLE 6. Mean value of perceived effects on local development $\left(I_{2}\right)$ by case study

\begin{tabular}{lcccc}
\hline & $\begin{array}{c}\text { Triglav } \\
\text { National Park } \\
(n=13)\end{array}$ & $\begin{array}{c}\text { Mis valley } \\
(\mathrm{n}=5)\end{array}$ & $\begin{array}{c}\text { Maè valley } \\
(\mathrm{n}=6)\end{array}$ & $\begin{array}{c}\text { Gesso- } \\
\text { Vermenagna } \\
\text { valley }(\mathrm{n}=8)\end{array}$ \\
\hline Local market diversification & 1.31 & 1.40 & 1.33 & 1.14 \\
Local entrepreneurship & 1.46 & 1.60 & 1.50 & 1.29 \\
Resource efficiency & 1.15 & 1.40 & 1.50 & 1.00 \\
Employment of local workforce & 1.69 & 1.60 & 1.67 & 1.25 \\
Increasing income per capita & 1.31 & 1.20 & 1.00 & 1.14 \\
Tourism & 0.23 & 1.40 & 1.67 & -0.29 \\
Social and community aggregation & 0.85 & 1.00 & 1.33 & 0.71 \\
Political stability & 0.23 & 1.00 & 1.17 & 0.43 \\
Human health & 0.00 & 1.00 & 1.00 & -0.29 \\
Property rights and rights of use & 0.85 & 0.60 & 1.33 & 0.50 \\
\hline Indicator 2 (mean) & 0.91 & 1.22 & 1.35 & 0.69 \\
\hline
\end{tabular}


local entrepreneurship, resource efficiency, employment of local workforce, and increasing income per capita. These results evidence that all the experts considered the use of forest biomass for energy as an important resource for local economic development, while the social and cultural effects are more controversial. Concerning social indicators, two indicators of quality of life obtained a score over 1, while the effects of biomass harvesting on the third one (tourism) were considered negative by the experts of Gesso-Vermenagna valley (-0.29).

The indicators of social stability (social and community aggregation, political stability) obtained positive values in all case studies, while the experts of the Gesso-Vermenagna valley considered the activity of biomass harvesting as potentially negative on human health $(-0.29)$. The effect of biomass harvesting on the property rights and rights of use was considered positive in all case studies.

The results of the third indicator $\left(I_{3}\right)$ show the potential energy obtained from forest biomass and are presented in Table 7. The differences in the potential energy from case studies are due to the annual increment and to the characteristics of tree species (wood density and energy content). Gesso-Vermenagna valley present the highest values of annual increment and many species with a high calorific value and wood density (e.g. European beech) form a significant part of the growing stock. On the other side, the low values of annual potential energy in Maè valley are mainly due to the high percentage of softwood species (Norway spruce and dwarf mountain pine).

Finally, the results of the fourth indicator $\left(\mathrm{I}_{4}\right)$ are reported in Figure 2. The costs collected in the case studies are higher than the data from literature: according to Asikainen et al. [51] in Eastern Europe the harvesting, extraction, chipping and transport costs of logging residues vary between 20-25€ $\mathrm{m}^{-3}$, while in Western Europe these costs vary between $30-35 € \cdot \mathrm{m}^{-3}$. These differences are due to the higher labour and fuel costs in Western European countries. In Veneto region (Mis and Maè valleys) the total costs (harvesting, extraction, chipping and transport costs) has been estimated at around $53 € \cdot \mathrm{t}^{-1}$ fresh wood chips and this value is comparable with the value reported in local literature $65 € \cdot \mathrm{t}^{-1}$ fresh wood chips [52]. The Triglav National Park case study shows costs slightly higher for harvesting (17 € $\mathrm{t}^{-1}$ fresh chips), while the Gesso-Vermenagna valley is in agreement with Mis and Mae Valley data (for harvesting $15 € \cdot \mathrm{t}^{-1}$ fresh chips and for extraction $26 € \cdot \mathrm{t}^{-1}$ fresh chips in Gesso-Vermenagna valley).

Finally, FoM was implemented with the support of the four above mentioned indicators (Table 8). From the theoretical point of view, in the present study FoM can vary from a minimum of 1 to a maximum of 10000 . The results show that the lowest FoM is found for the case studies of Maè valley (FoM $=60)$ and Gesso-Vermenagna valley (FoM $=60$ ), while the highest FoM is found for Triglav National Park (FoM $=1200)$. The greater sustainability of case studies located in Veneto Region is mainly influenced by results of the questionnaire, in particular by the fact that experts considered the forest biomass as an important resource for local development with few negative effects due to harvesting. In Triglav National Park the conservation objectives prevail. In the managed forests ( $2^{\text {nd }}$ and $3^{\text {rd }}$ protection zone) the forest management is more oriented to timber production than to wood for energy production. Forest biomass for energy production is a local product mainly used for home heating and deriving from private owned forests which prevail in the park.

TABLE 7. Annual potential energy $\left(I_{3}\right)$ by case study

\begin{tabular}{lcccc}
\hline & $\begin{array}{c}\text { Triglav } \\
\text { National Park }\end{array}$ & $\begin{array}{c}\text { Mis } \\
\text { valley }\end{array}$ & Maè valley & $\begin{array}{c}\text { Gesso-Vermenagna } \\
\text { valley }\end{array}$ \\
\hline Potential energy $\left(\mathrm{MJ}^{\prime} \mathrm{ha}^{-1}\right.$ year $\left.^{-1}\right)$ & 55090 & 56700 & 39440 & 98680 \\
\hline
\end{tabular}




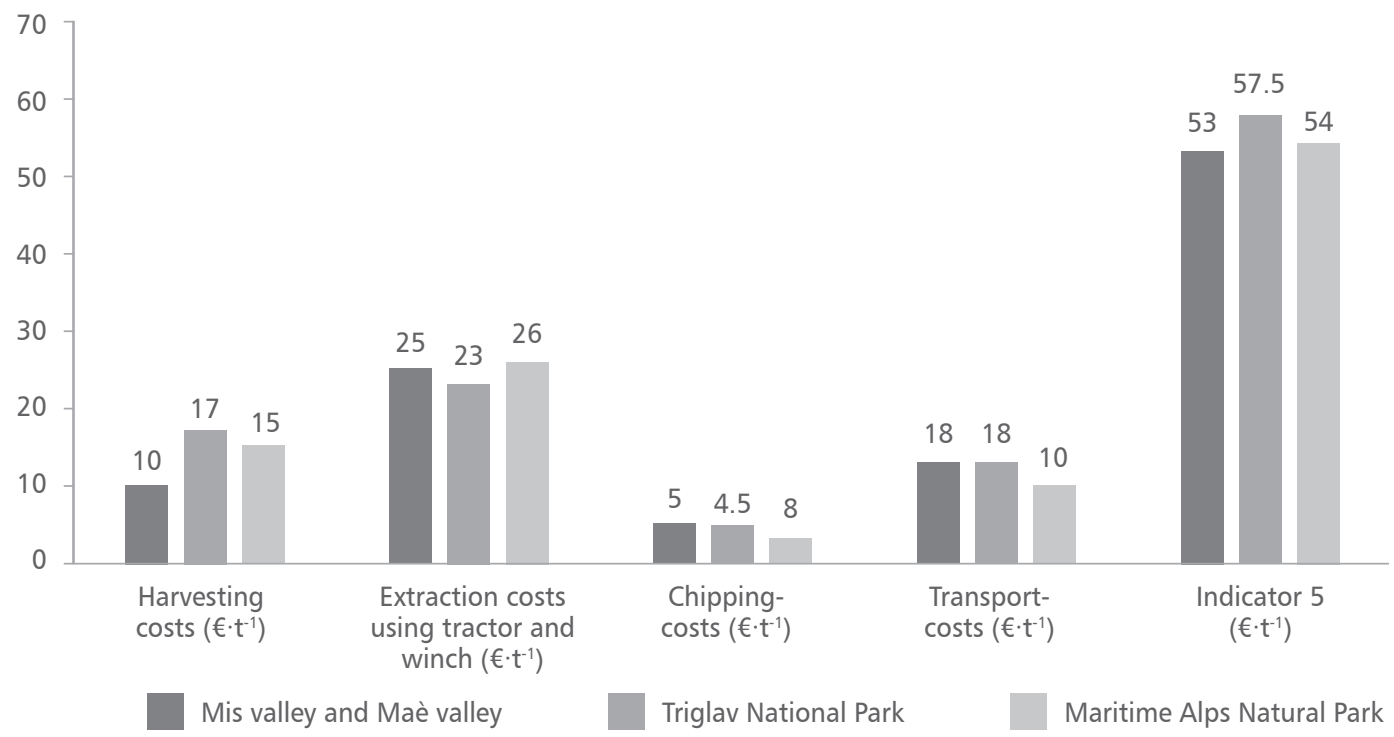

FIGURE 2. Average costs for wood chips production included the labour costs by case study (source: [52-55])

TABLE 8. Results of figure of merit (FoM) for forest biomass harvesting by case study

\begin{tabular}{|c|c|c|c|c|c|c|c|c|c|}
\hline & $I_{1}$ & $\begin{array}{l}\text { Relative } \\
\text { Rank I }\end{array}$ & $I_{2}$ & $\begin{array}{l}\text { Relative } \\
\text { Rank } \mathrm{I}_{2}\end{array}$ & $\mathrm{I}_{3}$ & $\begin{array}{l}\text { Relative } \\
\text { Rank } I_{3}\end{array}$ & $\mathrm{I}_{4}$ & $\begin{array}{l}\text { Relative } \\
\text { Rank } I_{4}\end{array}$ & FoM \\
\hline $\begin{array}{l}\text { Triglav National } \\
\text { Park }(n=13)\end{array}$ & 0.07 & 5 & 0.91 & 3 & 55090 & 8 & 57.5 & 10 & 1200 \\
\hline Mis valley $(n=5)$ & 0.55 & 4 & 1.22 & 2 & 56700 & 8 & 53 & 1 & 64 \\
\hline Maè valley $(n=6)$ & 1.06 & 3 & 1.35 & 2 & 39440 & 10 & 53 & 1 & 60 \\
\hline $\begin{array}{l}\text { Gesso-Vermenagna } \\
\text { valley }(n=8)\end{array}$ & 0.00 & 5 & 0.69 & 4 & 98680 & 1 & 54 & 3 & 60 \\
\hline
\end{tabular}

\section{DISCUSSION}

The results of the present research show that there are divergences between experts' opinions in the various study areas. These divergences are due to the different local economic, social and cultural contexts: perceptions and opinions regarding sustainability of forest biomass harvesting are deeply related to local conditions. In particular, concerning the perceived effects of biomass harvesting on forest products provision, probably the experts' evaluations take into consideration only the short-term effects of forest biomass harvesting. Conversely, the international literature shows that the long-term effects of forest biomass harvesting are influenced by complex relationships between harvesting and site nutrients which include the magnitude of nutrient removal and the rate of nutrient cycling [56]. In particular, removal of site organic matter and its associated nutrients may also reduce the concentrations of base cations in soils and foliage and adversely affect future productivity, if site nutrient status is not managed [57].

Concerning the effects on the habitat quality, the differences among case studies seem to be due to the perspective of analysis assumed by single experts. Most of the Italian experts 
declared that in their opinion removing the wood residues from forests decreases the risks of insect pollution, pests and fires, and increases the presence of different habitats. On the other side, the experts of Triglav National Park highlighted the negative effects of this activity on saproxylic insects and other deadwooddependent organisms. Negative opinions of Triglav National Park experts may also be related to the fact that conservation objectives prevail within the park area; outside the Triglav National Park boundaries the opinions of experts could be different. In fact, Nijnik et al. [58] assert that the removal of residues and deadwood changes pest population and composition and affect their predator, while other authors evidence that the normal utilization of wood residues after forest operations has a negative impact on wildlife and biodiversity $[14,59]$. This negative effect is due to the importance of deadwood components (standing snags, stumps, fallen logs, broken off tops and limbs, twigs) in order to supply food and cover resources for many wildlife species [60, 61]. In addition, Nijnik et al. [58] identified three types of negative effects of residue and deadwood extraction (logging residues attract species laying eggs in the piles, soil disturbance affects mosses and species reproducing in the vegetation, and deadwood extraction leads to habitat fragmentation for dependent species), and only one positive impact (removing stumps leads to an increase of sapling of deciduous species).

In addition, most of experts of Veneto Region (Mis and Maè valleys) affirmed that the long practice of close-to-nature forest management can always guarantee the preservation of forest habitat and - at the same time - the wood cutting can help the establishment of the right balance between open areas and the forest itself. This is important not only for recreational values but also for the preservation of habitat mosaic and for the major ecological variability. In general, we cannot always affirm that the harvesting operations, both of standing trees and other biomass, tend to reduce the structural complexity of a forest stand, but surely influence various physical features of the forest landscape and consequently the recreational value. Moreover, forest biomass harvesting can have positive effects on biodiversity, but harvesting effects and deadwood removal can also produce negative effects on habitat. Management strategies and policy measures must take into consideration experts' opinions and evaluations, weighting and combining them in efficient ways.

Regarding the local development, the results highlight that economic, social and environmental dimensions derived from experts' evaluations must be combined from separate aspects to a unified and multifaceted issue. For example, on one side forest biomass harvesting is considered as a source for local development, and a crucial matter for local community aggregation; on the other side, experts focused their attention also on the possible impacts of biomass power plants, especially for what concerns atmospheric emissions.

In the case studies of Veneto Region, the high scores that experts assigned to the effects of biomass harvesting on employment, local entrepreneurship and community aggregation are related to the past tradition of wood cutting and working. In fact most of the experts perceived biomass harvesting as a practice that could implement again forest related activities, and this role is central as a source of job opportunities to develop the area and maintain people in their territory. Only two sub-indicators show divergences between case studies: human health and tourism. Most of Triglav National Park's experts during the interviews declared that in their opinion bioenergy development is not a tool to increase people participation in decision making process and tourism flows. Besides, around half of the Slovenian experts considered as neutral the effects on human health, while the Italian experts emphasized the positive effects of wood residues removal regards to the insects dangerous for human safety (e.g. Thaumetopoea pityocampa L. and Thaumetopoea processionea L.).

The two indicators related to the annual potential energy and costs are deeply related to local species characteristics $\left(I_{3}\right)$ and to the specific conditions of work in the forest sector $\left(\mathrm{I}_{4}\right)$. These 
indicators can be useful for decision makers in order to carry out a cost-benefit analysis of forest biomass for energy use. We can assert that the most important indicators of FoM are the effects of forest biomass harvesting on ESs and local development $\left(I_{1}\right.$ and $\left.I_{2}\right)$ because they include all the most important environmental, economic and social aspects. In order to take in consideration the different relevance of indicators, in future applications of FoM to assess the sustainability of bioenergy the four indicators could be weighed differently giving more weight to the effects on ESs and local development.

\section{CONCLUSIONS}

In conclusion, the results of our research show that, according to experts' opinions, forest biomass harvesting for energy has positive effects on most of the ESs. In the specific, environmental sustainability is important in order to maintain a certain standing stock in forest, a long term site productivity and a good level of biodiversity [62]. Economic sustainability is the engine for new business investments, the innovative technologies development and the local economic growth. In particular, the results of this study confirm that the forest biomass use for energy purpose could have positive effects on the creation of new job opportunities and on the diffusion of innovation. Social sustainability is fundamental for ensuring successful formulation and implementation of energy policy, in order to reduce conflicts and improving cooperation among the different groups of interest [63]. Besides, social sustainability is crucial in order to reduce the divergences between local community and decision makers, to increase the inclusiveness of participatory decision making process, and to decrease the conflicts between land users [64]. The results confirm that the forest biomass harvesting for energy could potentially have positive effects on the quality of life of local communities and social cohesion.

The proposed method based on FoM allows comparing and evaluating synthetically the single case studies in order to highlight any critical points or inefficiencies. The advantages of the method are the simplicity of implementation and the possibility of taking into account simultaneously qualitative variables (e.g. experts' perceptions) and quantitative variables (e.g. costs). The combined analysis of social, economic and environmental sustainability can give clear guidance to decision makers to improve the efficiency of the use of forest biomass for energy, reducing the effects on the environment in general and the ESs in particular.

The main limit of the method is the inability to consider all relevant aspects from the political and technical point of view.

The future steps of the analysis will focus on an integration of the indicators to be used in the FoM in order to consider all aspects of forest biomass harvesting for energy. Besides, the method will be extended to a comparison of the different renewable energies in the case studies considered in the Recharge.green project.

\section{Acknowledgements}

This study was conducted in the frame of the Recharge.Green project "Balancing Alpine Energy and Nature" (http://www.recharge-green. eu), which is carried out within the Alpine Space Programme, and is co-financed by the European Regional Development Fund. The Recharge.Green project is focused on the analysis of how to reconcile biodiversity conservation of ecosystems and renewable energy production. The authors would like to thanks Simone Bertin, Stefano Sisto, Erica Zangrando (Veneto Region, Department of Economy and Development in Mountain Areas), Tomaž Kralj and Renata Rozman (Triglav National Park), Tina Simončič and Špela Ščap (Biotechnical Faculty of the University of Ljubljana), Luca Giraudo (Maritime Alps Natural Park), Geitner Clemens and Hastik Richard (Department of Geography, University of Innsbruck) and all the experts who answered to the questionnaire. We are also grateful to two anonymous referees whose comments considerably helped to improve the article. 


\section{REFERENCES}

1. VARUN, PRAKASH R, BHAT IK 2009 Energy, economics and environmental impacts of renewable energy systems. Renew Sust Energ Rev 13 (9): 2716-2721. DOI: http://dx.doi. org/10.1016/j.rser.2009.05.007

2. AKELLA AK, SAINI RP, SHARMA MP 2009 Social, economical and environmental impacts of renewable energy systems. Renew Energ 34 (2): 390-396. DOI: http://dx.doi.org/10.1016/j. renene.2008.05.002

3. YLITALO E, MUSTONEN M 2014 Consumption of renewable energy and wood fuels in the European Union. In: Pelkonon P, Mustonen M, Asikainen A, Egnell G, Kant P, Ledue S, Pettenella D (eds) Forest Bioneergy for Europe, What Science Can Tell Us 4, European Forest Institute, Joensuu, Finland, pp 17-22

4. EC 2006 Communication from the Commission to the Council and the European Parliament on an EU Forest Action Plan. COM(2006) 302 Final. Commission of the European Communities, Brussels, Belgium, 13 p. URL: http://ec.europa. eu/agriculture/fore/action_plan/com en.pdf (3 September 2014).

5. VERKERK PJ, ANTTILA P, EGGERS J, LINDNER M, ASIKAINEN A 2011 The realisable potential supply of woody biomass from forests in the European Union. Forest Ecol Manag 261 (11): 2007-2015. DOI: http://dx.doi.org/10.1016/j. foreco.2011.02.027

6. MASIERO M, MUYS B, SOLBERG B 2014 Forestrelated policies affecting bioenergy markets in Europe. In: Pelkonen P, Mustonen M, Asikainen A, Egnell G, Kant P, Ledue S, Pettenella D (eds) Forest Bioenergy for Europe, What Science Can Tell Us 4, European Forest Institute, Joensuu, Finland, pp 23-28

7. FAO 2010 Global Forest Resources Assessment 2010. Main Report. FAO Forestry Paper 163. Food and Agriculture Organization of the United Nations, Rome, Italy. URL: http://www.fao.org/ docrep/013/i1757e/i1757e.pdf (1 September 2014)

8. MANTAU U, SAAL U, PRINS K, STEIERER F, LINDNER $\mathrm{M}$, VERKERK H, EGGERS J, LEEK N, OLDENBURG J, ASIKAINEN A, ANTTILA P 2010 EUwood - Real potential for changes in growth and use of EU forests. Final report. Hamburg, Germany, $160 p$
9. BEURSKENS LWM, HEKKENBERG M, VETHMAN P 2011 Renewable energy projections as published in the national renewable energy action plans of the European Member states. ECN and EEA, Brussels, Belgium, 244 p. URL: http://www. ecn.nl/docs/library/report/2010/e10069.pdf September 2014)

10. DEES M, YOUSEF A, ERMERT J 2011 Analysis of the quantitative tables of the national renewable energy action plans prepared by the 27 European Union Member States in 2010. BEE working paper D7.2. Biomass Energy Europe project. FELIS Department of Remote Sensing and landscape information systems, University of Freiburg, Freiburg, Germany.

11. NABUURS G, PUSSINEN A, VAN BRUSSELEN J, SCHELHAAS M 2007 Future harvesting pressure on European forests. Eur J Forest Res 126 (3): 391400. DOI: http://dx.doi.org/10.1007/s10342-0060158-y

12. WORLD COMMISSION ON ENVIRONMENT AND DEVELOPMENT 1987 Our Common Future. Oxford University Press, Oxford, UK, $400 \mathrm{p}$

13. HUTCHINS MJ, SUTHERLAND JW 2008 An Exploration of Measures of Social Sustainability and Their Application to Supply Chain Decisions. J Clean Prod 16 (15): 1688-1698. DOI: http://dx.doi. org/10.1016/j.jclepro.2008.06.001

14. IEA 2002 Sustainable production of woody biomass for energy. A position paper prepared by IEA Bioenergy. IAE Bioenergy, Rotorua, New Zeland, $12 \mathrm{p}$

15. MORELLI J 2011 Environmental Sustainability: A Definition for Environmental Professionals. J Environ Sust 1 (1): 19-27. DOI: http://dx.doi. org/10.14448/jes.01.0002

16. EHRLICH PR, EHRLICH AH 1981 Extinction: the causes and consequences of the disappearance of species. Random House, New York, NY, USA, 305 p

17. MOONEY H, EHRLICH P 1997 Ecosystem services: a fragmentary history. In: Daily GC (ed), Nature's Services. Island Press, Washington DC, USA, pp 11-19

18. DAILY GC 1997 Nature's Services: Societal Dependence on Natural Ecosystems. Island Press, Washington, DC, USA, $392 p$ 
19. COSTANZA R, D'ARGE R, DE GROOT R, FARBER $S$, GRASSO M, HANNON B, LIMBURG K, NAEEM $S$, et al. 1997 The value of the world's ecosystem services and natural capital. Nature 387: 253-260. DOI: http://dx.doi.org/10.1038/387253a0

20. MILLENNIUM ECOSYSTEM ASSESSMENT 2005 Ecosystems and Human Well-being, Island Press Washington, DC, USA, 137 p. URL: http:// www.millenniumassessment.org/documents/ document.356.aspx.pdf (5 September 2014)

21. TEBB 2010 The economics of ecosystems and biodiversity: mainstreaming the economics of nature: a synthesis of the approach, conclusions and recommendations of TEEB. URL: http://www. unep.org/pdf/LinkClick.pdf (5 September 2014)

22. EUROPEAN ENVIRONMENT AGENCY 2013 Common International Classification of Ecosystem Services Version 4.3. URL: http://cices.eu/ (5 September 2014)

23. CONWAY GR, BARBIER EB 1990 After the Green Revolution: Sustainable agriculture for development. Earthscan Publications Ltd, London, UK, $205 p$

24. PEARCE D, MARKANDYA A, BARBIER E 1989 Blueprint for a Green Economy. Earthscan Publications Ltd, London, UK, $192 \mathrm{p}$

25. CIEGIS R, RAMANAUSKIENE J, MARTINKUS B 2009 The Concept of Sustainable Development and its Use for Sustainability Scenarios. Inzinerine Ekonomika-Engineering Economics 2: 28-37

26. MCKENZIE S 2004 Social sustainability: towards some definitions. Hawke Research Institute Working Paper Series 27. Hawke Research Institute and University of South Australia, Magill, South Australia, Australia, 31 p. URL: http://w3.unisa. edu.au/hawkeinstitute/publications/downloads/ wp27.pdf (4 September 2014)

27. PARRIS TM, KATES RW 2005 Characterizing and measuring sustainable development. Ann Rev Environ Resour 28: 559-586. DOI: http://dx.doi. org/10.1146/annurev.energy.28.050302.105551

28. PAlEtTO A, DE MEO I, DI SAlVATORE U, FERRETTI F 2014 Perceptions of Sustainable Forest Management practices: an application from the forestry sector in southern Italy. Int Forest $\operatorname{Rev} 16$ (1): 55-66. DOI: http://dx.doi. org/10.1505/146554814811031224
29. SVADLENAK-GOMEZ K, BADURA $M$, KRAXNER $F$ FUSS S, VETTORATO D, WALZER C 2013 Valuing Alpine ecosystems: the Recharge.green project will help decision-makers to reconcile renewable energy production and biodiversity conservation in the Alps. Eco.mont - Journal of protected mountain areas research 5 (1): 51-54. DOI: http:// dx.doi.org/10.1553/eco.mont-5-1s59

30. RAUDSEPP-HEARNE $C$, PETERSON GD, TENGÖ $M$, BENNETT EM, HOLLAND T, BENESSAIAH K, MACDONALD GK, PFEIFER L 2010 Untangling the environmentalist's paradox: Why is human wellbeing increasing as ecosystem services degrade? BioScience 60 (8): 576-589

31. FOLYD A 1968 Trend forecasting: A methodology for figure of merit. In: Bright J (ed) Technological forecasting for Industry and Government: Methods and Applications, Prentice-Hall, New Jersey, USA, pp 95-105

32. MULLICK SC, KANDPAL TC, KUMAR S 1996 Testing of box-type solar cooker: second figure of merit $\mathrm{F}_{2}$ and its variation with load and number of pots. Sol Energy 57 (5): 409-413. DOI: http://dx.doi. org/10.1016/S0038-092X(96)00116-8

33. FISHER B, TURNER RK, MORLING P 2009 Defining and classifying ecosystem services for decision making. Ecol Econ 68 (3): 643-653. DOI: http:// dx.doi.org/10.1016/j.ecolecon.2008.09.014

34. MARTEEL AE, DAVIES JA, OLSON WW, ABRAHAM MA 2003 Green chemistry and engineering: drivers, metrics, and reduction to practice. Ann Rev Environ Resour 28: 401-428. DOI: http://dx.doi. org/10.1146/annurev.energy.28.011503.163459

35. GALLEGO CARRERA D, MACK A 2010 Sustainability assessment of energy technologies via social indicators: Results of a survey among European energy experts. Energ Policy 38 (2): 1030-1039. DOI: http://dx.doi.org/10.1016/j. enpol.2009.10.055

36. GERBNER G 1969 Towards 'Cultural Indicators': The analysis of mass mediated message systems. AV Commun Rev 17 (2): 137-148

37. ADAMS PW, HAMMOND GP, MCMANUS MC, MEZZULLO WG 2011 Barriers to and drivers for UK bioenergy development. Renew Sust Energ Rev 15 (2): 1217-1227. DOI: http://dx.doi.org/10.1016/j. rser.2010.09.039 
38. BRUKMAJSTER D, HAMPEL J, RENN O 2007 Energy technology road map and stakeholders' perspective: establishment of social criteria for energy systems. Stuttgarter Beiträge Zur Risiko- und Nachhaltigkeitsforschung Institut Fürn SozialwissenschaftenAbt. Für Technikund Umweltsoziologie, Universität Stuttgart. , Stuttgart, Germany, $100 \mathrm{p}$

39. BUCHHOLZ T, LUZADIS V, VOLK TA 2009 Sustainability criteria for bioenergy systems: results from an expert survey. J Clean Prod 17 (1): S86-S98. DOI: http://dx.doi.org/10.1016/j. jclepro.2009.04.015

40. COFFEY W, POLESE M 1984 The concept of local development: a stages model of endogenous regional growth. Pap Reg Sci 55 (1): 1-12. DOI: http://dx.doi.org/10.1111/j.1435-5597.1984. $\underline{\mathrm{tb} 00823 . x}$

41. DEL RÍO P, BURGUILLO M 2008 Assessing the impact of renewable energy deployment on local sustainability: Towards a theoretical framework. Renew Sust Energ Rev 12 (5): 1325-1344. DOI: http://dx.doi.org/10.1016/i.rser.2007.03.004

42. EPPINK FV, VAN DEN BERGH JC, RIETVELD P 2004 Modelling biodiversity and land use: urban growth, agriculture and nature in a wetland area. Ecol Econ 51 (3-4): 201-216. DOI: http://dx.doi. org/10.1016/j.ecolecon.2004.04.011

43. JIANG JIANG W, YOU YIN J, CHUN FA Z, JUN HONG Z 2009 Review on multi-criteria decision analysis aid in sustainable energy decision making. Renew Sust Energ Rev 13 (9): 2263-2278. DOI: http:// dx.doi.org/10.1016/j.rser.2009.06.021

44. NGUYEN KQ 2007 Alternatives to grid extension for rural electrification: Decentralized renewable energy technologies in Vietnam. Energ Policy 35 (4): 2579-2589. DOI: http://dx.doi.org/10.1016/j. enpol.2006.10.004

45. OLUSOGA SA 1993 Market concentration versus market diversification and internationalization: implications for MNE performance. Int Market Rev 10 (2): 107-120

46. SALA S, CASTELLANI V 2011 Technology sustainability assessment to support decision making on energy production at local scale. Int J Sus Dev Plann 6 (3): 251-267

47. BRONFMAN NC, JIMÉNEZ RB, ARÉVALO PC, CIFUENTES LA 2012 Understanding social acceptance of electricity generation sources. Energ policy 46: 246-252. DOI: http://dx.doi. org/10.1016/j.enpol.2012.03.057
48. FRANCESCATO V, ANTONIN E, ZUCCOLI BERGOMI L 2008 Wood fuels handbook. AIEL - Italian Agroforestry Energy Association, Padua, Italy, 79 p. URL: http://www.aebiom.org//MG/pdf/WOOD FUELS HANDBOOK BTC EN.pdf (3 September 2014)

49. ILARIONI L 2007 II legno come combustibile: caratteristiche energetiche e di prodotto (in Italian). Silvæ 7: 203-214

50. HOLZLEITNER F, STAMPFER K, VISSER R, 2011 Utilization rates and cost factors in timber harvesting based on long-term machine data. Croat J Forest Eng 32 (2): 501-508

51. ASIKAINEN A, BJÖRHEDEN R, MOFFAT AJ, SPINELLI R 2014 From biomass to feedstock. In: Pelkonen $P$, Mustonen M, Asikainen A, Egnell G, Kant P, Ledue $S$, Pettenella D (eds) Forest Bioenergy for Europe, What Science Can Tell Us 4, European Forest Institute, Joensuu, Finland, pp 66-67

52. AGOSTINETTO L, CANZAN L, FRESCURA C, AGUANNO M 2008 Una filiera locale del legno cippato. L'impianto di riscaldamento per la sede della Comunità Montana Feltrina (in Italian). Azienda Regionale Veneto Agricoltura, Padua, Italy, $55 \mathrm{p}$

53. SPINELLI R, MAGAGNOTTI N, HARTSOUGH B 2006 Raccolta integrate di tondame e biomassa nel taglio a gruppi di fustaie alpine (in Italian). L'Italia Forestale e Montana 4: 303-316. DOI: http:// dx.doi.org/10.4129/IFM.2006.4.04 (5 September 2014)

54. SPINELLI R, NATI C, AGOSTINETTO L, FRANCESCATO V, ANTONINI E 2004 Produzione di cippato ottenuto dal diradamento di un arboreto per la produzione di legname di pregio (in Italian). Azienda Regionale Veneto Agricoltura, Padua, Italy, $12 \mathrm{p}$

55. REGIONE PIEMONTE 2014 Prezzi di riferimento per opere e lavori pubblici nella Regione Piemonte. Assessorato alla opere Pubbliche, Regione Piemonte, Torino, Italy

56. KIMMINS JP 1976 Evaluation of the consequences for future tree productivity of the loss of nutrients in whole-tree harvesting. Forest Ecol Manag 1: 169-183. DOI: http://dx.doi.org/10.1016/03781127(76)90019-0

57. THIFFAULT E, HANNAM KD, PARÉ D, TITUS BD, HAZLETT PW, MAYNARD DG, BRAIS S 2011 Effects of forest biomass harvesting on soil productivity in boreal and temperate forests - A review. Environ Rev 19: 278-309. DOI: http://dx.doi.org/10.1139/ a11-009 
58. NIJNIK M, SLEE B, NIJNIK A 2014 Biomass production: impacts on other ecosystem services. In: Pelkonen P, Mustonen M, Asikainen A, Egnell G, Kant P, Ledue S, Pettenella D (eds) Forest Bioenergy for Europe, What Science Can Tell Us 4. European Forest Institute, Joensuu, Finland, pp 82-89

59. HARMON ME, CROMACK K, SMITH BG 1987 Coarse Woody Debris in Mixed-Conifer Forests, Sequoia-National-Park, California. Can J Forest Res 17 (10): 1265-1272. DOI: http://dx.doi. org/10.1139/x87-196

60. HUNTER ML 1990 Wildlife, Forests and Forestry: Principles of Managing Forests for Biological Diversity Prentice Hall Upper Saddle River, NJ, USA, $259 \mathrm{p}$

61. HAGAN JM, GROVE SL 1999 Coarse woody debris. J Forest 97 (1): 6-11
62. STUPAK I, ASIKAINEN A, JONSELL M, KARLTUN E, LUNNAN A, MIZARAIT D, TAMMINEN P 2007 Sustainable utilisation of forest biomass for energy - Possibilities and problems: Policy, legislation, certification, and recommendations and guidelines in the Nordic, Baltic, and other European countries. Biomass Bioenerg 31 (10): 666-684. DOI: http://dx.doi.org/10.1016/j. biombioe.2007.06.012

63. DWIVEDI P, ALAVALAPATI JRR 2009 Stakeholders' perceptions on forest biomass-based bioenergy development in the southern US. Energ Policy 37 (5): 1999-2007. DOI: http://dx.doi.org/10.1016/j. enpol.2009.02.004

64. HALL J P 2002 Sustainable production of forest biomass for energy. Forest Chron 78 (3): 391-396. DOI: http://dx.doi.org/10.5558/tfc78391-3

(C) 2015 by the Croatian Forest Research Institute. This is an Open Access paper distributed under the terms of the Creative Commons Attribution License (http://creativecommons.org/licenses/by/4.0). 